\title{
EFFECT OF WATER TABLE LEVEL ON YIELD AND ROOT SYSTEM OF PLANTAINS ${ }^{1,2}$
}

\author{
Heber Irizarry, Servando Silva and José Vicente-Chandler ${ }^{3}$ \\ ABSTRACT
}

Plantains produced $5,650,25,550,37,800$ and $32,260 \mathrm{~kg} / \mathrm{ha}$ when the water table of a Mollisol was maintained at depths of $12,24,36$ and $48 \mathrm{~cm}$, respectively. Roots in the upper $15 \mathrm{~cm}$ of soil were not affected by depth of the water table. Lowering the water table from 12 to $48 \mathrm{~cm}$ increased roots at the 15 to $30 \mathrm{~cm}$ depth from 232 to $646 \mathrm{~cm} / 1,000 \mathrm{~cm}^{3}$ of soil, and at the 30 to $45 \mathrm{~cm}$ depth from 92 to $498 \mathrm{~cm} / 1,000 \mathrm{~cm}^{3}$ of soil.

\section{INTRODUCTION}

Although plantains are a major food crop in the humid tropics only about $25 \%$ enter commercial markets, and there is little research information on their cultural requirements. Plantains have recently been receiving more attention because large scale commercial plantings have been developed in the Dominican Republic, Ecuador, Colombia, Venezuela, Nicaragua, and Puerto Rico.

Information on the effect of water table level on plantain yields and root development is valuable in designing drainage systems and selecting areas best suited to plantain production. The effect of water table levels on bananas (Musa acuminata) has been studied by Ghavami ${ }^{4}$, among others, but the authors have found no reference to such studies with plantains (Musa acuminata $\times M$. balbisiana). However, they have observed that plantains do not do well on poorly drained soils, and Abruña et al. ${ }^{5}$ found that, on heavy soils, irrigating plantains too frequently decreases yield.

This study was conducted to determine the effect of four water table levels on the yield and root system of plantains.

\section{MATERIALS AND METHODS}

The experiment was conducted at Río Piedras at an elevation of about $30 \mathrm{~m}$. Average annual temperature is about $26^{\circ} \mathrm{C}$ and average monthly

${ }^{1}$ Manuscript submitted to Editorial Board December 1, 1978.

${ }^{2}$ This paper covers work carried out cooperatively between the Science and Education Administration, USDA, and the Agricultural Experiment Station, Mayagüez Campus, University of Puerto Rico, Río Piedras, P.R.

${ }^{3}$ Horticulturist, Research Technician and Soil Scientist, Science and Education Administration, USDA, Río Piedras, P.R., respectively.

4 Ghavami, M., Banana Plant Response to Water Table Levels, ASAE 19 (4), 675-7, 1976.

${ }^{5}$ Abruña, F., Vicente-Chandler, J., Irizarry, H., and Silva, S., Evapotranspiration by plantains and the effect of frequency of irrigation on yields. In press, Jr. Agri. Univ. P.R. 
variation is about $5^{\circ} \mathrm{C}$. Annual rainfall is about $2,000 \mathrm{~mm}$. The winter is fairly dry, rains are heavy in the fall.

Sixteen concrete lysimeter tanks $1.2 \mathrm{~m}$ wide, $2.4 \mathrm{long}$ and $48 \mathrm{~cm}$ deep were used in this experiment. The lysimeters were filled with Toa clay loam (Mollisol) which was allowed to settle over a 2-mo period to its normal bulk density of about 1.3. The soil had a pH of $5.8,3.8 \%$ of organic matter, 22 me of exchange capacity and 14 me of exchangeable bases/100 $\mathrm{g}$ of soil.

Two suckers of a high yielding selection of the Maricongo cultivar were planted in each lysimeter tank. The plants were spaced at $1.2 \times 2.4 \mathrm{~m}$ which is equivalent to about 3,500 plants/ha, close to optimum for this crop, as Irizarry, Green and Hernández ${ }^{6}$ have shown. The suckers were peeled and dipped in an insecticide-nematicide solution before planting. These pesticides were later applied in granular form around each plant every 4 mo. Fertilizer was applied at the rate of $700 \mathrm{~kg}$ of $10-5-20 / \mathrm{ha}$ every 4 mo. No spraying was necessary because Cercospora leaf spot was not a problem. The suckers were planted in January 1977 and harvesting was completed July 1978.

The treatments, replicated four times and initiated 4 months after planting, consisted of maintaining a free water table at 12, 24, 36 and 48 $\mathrm{cm}$ below the soil surface. The water table was maintained at the desired level in the lysimeters by adjusting the level of water in connecting open tanks. The plants were watered once a week whenever there was little or no rainfall.

Ten months after planting, just before the plants started to flower, soil samples $(30 \times 30 \mathrm{~cm} \times 15 \mathrm{~cm}$ deep) were taken at four locations in each treatment at 0 to 30 and 30 to $60 \mathrm{~cm}$ from the plantain pseudostems and at the 0 to 15,15 to 30 and 30 to $45 \mathrm{~cm}$ depths. The roots in each soil sample were carefully removed by hand and measured.

\section{RESULTS AND DISCUSSIONS}

Table 1 shows that the number of plantains produced increased from 40,250 to $155,050 /$ ha when the water table level was lowered from 12 to $24 \mathrm{~cm}$. No further increase in number of plantains occurred as a result of further lowering the water table to 36 and $48 \mathrm{~cm}$.

Yields of plantains were $5,650,25,550$ and $37,800 \mathrm{~kg} / \mathrm{ha}$ when the water table was maintained at 12,24 and $36 \mathrm{~cm}$, respectively, but no further increase in yields resulted from lowering the water table to $48 \mathrm{~cm}$.

Figure 1 shows the effect of the water table level on the root system of plantains. The water table level did not appreciably affect root development in the upper $15 \mathrm{~cm}$ of soil. However, plantain roots in the 15 to 30

${ }^{6}$ Irizarry, H., Green, J., and Hernández, I., Effect of plant density on yield and other quantitative characters of Maricongo plantains, J. Agri. Univ. P.R., 59 (4):245-54, 1975. 
PLANTAINS: EFFECT OF WATER TABLE LEVEL ON YIELD, ROOTS

TABLE 1.-Effect of water table level on yield of plantains

\begin{tabular}{crc}
\hline Depth to water table & \multicolumn{2}{c}{ Yields of plantains } \\
\hline Cm $m$ & Number/ha & Kg/ha \\
12 & $40,250 \mathrm{a}^{\prime}$ & $5,650 \mathrm{a}$ \\
24 & $155,050 \mathrm{~b}$ & $25,550 \mathrm{~b}$ \\
36 & $156,450 \mathrm{~b}$ & $37,800 \mathrm{c}$ \\
48 & $141,050 \mathrm{~b}$ & $32,200 \mathrm{c}$
\end{tabular}

'Figures within columns followed by the same letter do not differ statistically.

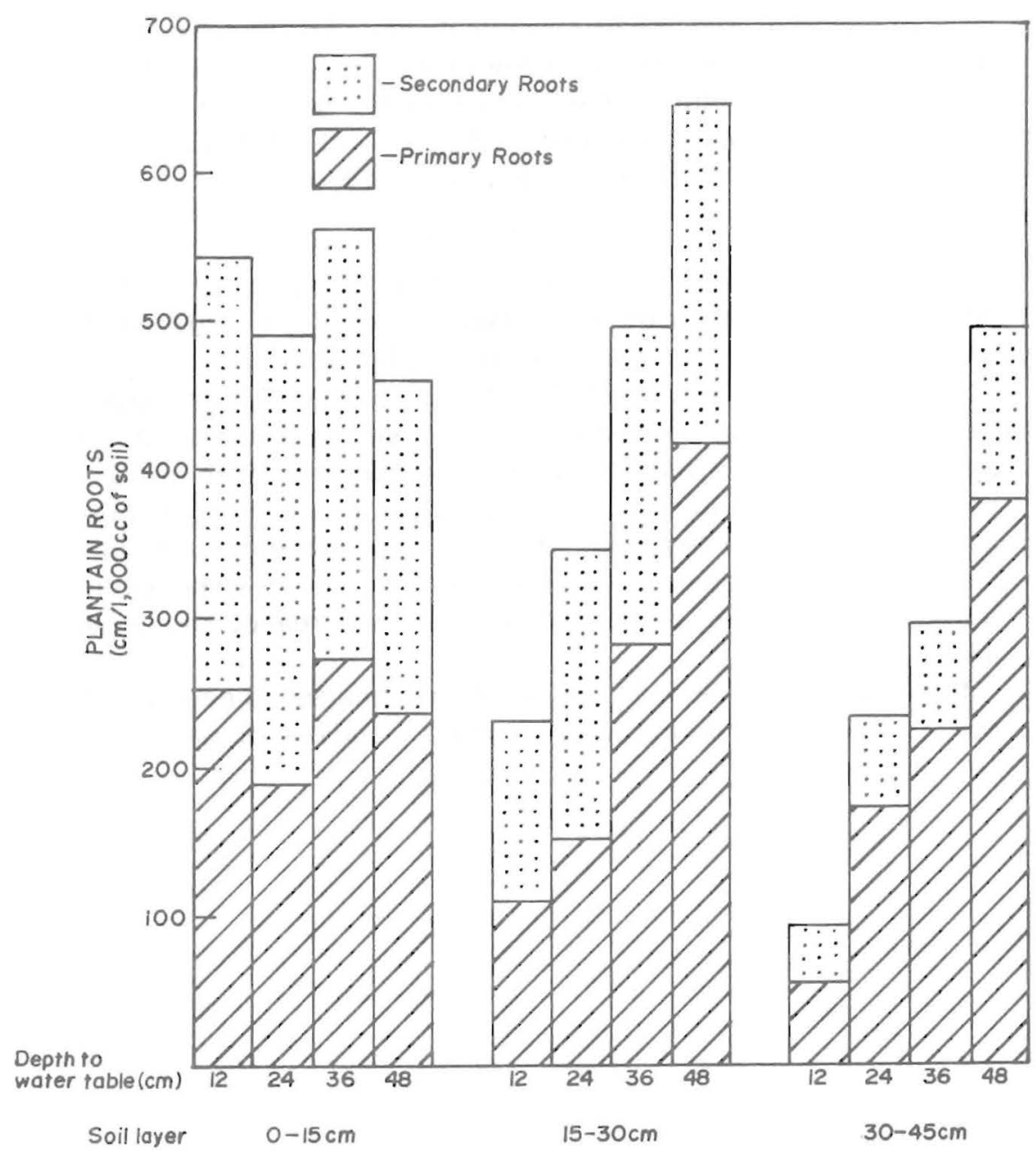

FiG. 1.-Effect of depth of water table on plantain roots. 
$\mathrm{cm}$ soil layer increased markedly with each drop in the water table level from $232 \mathrm{~cm} / 1,000 \mathrm{~cm}^{3}$ of soil when the water table was maintained at 12 $\mathrm{cm}$ to $646 \mathrm{~cm} / 1,000 \mathrm{~cm}^{3}$ of soil, with a free water table at $48 \mathrm{~cm}$. Roots in the 30 to $45 \mathrm{~cm}$ layer also increased with each lowering of the free water table from $92 \mathrm{~cm} / 1,000 \mathrm{~cm}^{3}$ of soil when the water table was maintained at $12 \mathrm{~cm}$ to $498 \mathrm{~cm} / 1,000 \mathrm{~cm}^{3}$ of soil with a free water table at $48 \mathrm{~cm}$.

Figure 1 also shows that the secondary roots generally decreased more with depth in the soil than did the primary roots. However, the primary roots responded more to lowering of the water table than did the secondary roots.

These results show that to obtain high yields and good root development of plantains, the free water table must be kept at least $36 \mathrm{~cm}$ below the soil surface. Maintaining a low water table permits the roots to explore a greater volume of soil which increases resistance to drought, improves use of applied fertilizer and of natural soil fertility and better anchors these plants, which are often toppled by wind.

\section{RESUMEN}

Se determinó el efecto de mantener el nivel freático a 12, 24, 36 y 48 $\mathrm{cm}$ de profundidad en un suelo Toa arcilloso lómico (Mollisol) en la producción y desarrollo de las raíces del platanero.

Se produjeron $4,650,25,550,37,800$ y $32,200 \mathrm{~kg}$ de plátanos por hectárea cuando el nivel freático del suelo se mantuvo a 12, 24, 36 y 48 $\mathrm{cm}$ de profundidad, respectivamente. La cantidad de raíces en los 15 $\mathrm{cm}$ superiores de suelo no se afectaron por el nivel freático, pero en la zona de 15 a $30 \mathrm{~cm}$ de profundidad las raíces aumentaron de 232 a 646 $\mathrm{cm} / 1,000 \mathrm{~cm}^{3}$ de suelo y en la zona de 30 a $45 \mathrm{~cm}$ aumentaron de 92 a $498 \mathrm{~cm} / 1,000 \mathrm{~cm}^{3}$ de suelo cuando el nivel freático se bajó de 12 a $48 \mathrm{~cm}$.

Estos resultados señalan que, en los platanales, es necesario mantener el nivel freático de los suelos a una profundidad de por lo menos 36 $\mathrm{cm}$. 